\title{
Comparative Effects of the Synchronous and the Asynchronous Instructional Approaches Concerning the Students' Achievements and Interests in Electrical Engineering at the Niger State College Of Education
}

\author{
http://dx.doi.org/10.3991/ijep.v6i3.5302 \\ E. Raymond ${ }^{1}$, B.N. Atsumbe ${ }^{1}$, R.O. Okwori ${ }^{1}$ and M.A. Jebba ${ }^{2}$ \\ ${ }^{1}$ Federal University of Technology, Minna, Nigeria \\ ${ }^{2}$ Niger State College of Education, Minna, Nigeria
}

\begin{abstract}
This study was conducted to determine the comparative effects of the synchronous and the asynchronous instructional approaches on College of Education students' achievements and interests in electrical engineering. The population of the study comprises of 190 electrical engineering students. A quasi-experimental research design was adopted. Two research questions and two hypotheses tested at a 0.05 level of significance guided the study. The research questions were answered using Mean and Standard Deviations while the Analysis of Covariance (ANCOVA) was employed to test the hypotheses. The study revealed that the asynchronous instructional approach was more effective in improving the students' achievements and stimulated their interest in learning more than the synchronous instructional approach. The study also found out that there was a significant difference in the cognitive achievement of students taught Electrical Engineering with the asynchronous instructional approach than those taught with the synchronous instructional approach. However, there was no significant difference between the mean interest scores of students taught Electrical Engineering with the asynchronous instructional approach and those taught with the synchronous instructional approach. On the basis of these findings, the study recommends, among others things, that the National Commission for Colleges of Education should develop the appropriate framework necessary for encouraging the adoption of the innovative e-learning platform such as that of the synchronous and the asynchronous instruction while the management of the Colleges of Education under study should institutionalize and encourage lecturers to use asynchronous instruction in teaching. Finally, the Lecturers should adopt the asynchronous instructional approach in teaching and learning Electrical Engineering in the Colleges of Education under study.
\end{abstract}

Index Terms-Achievement, asynchronous instruction, Electrical Engineering, NCE students, Nigerian College of Education, synchronous instruction,

\section{INTRODUCTION}

The use of Information and Communication Technology (ICT) is increasingly influencing the way teachers teach and the way learners learn. The rapid global trans- formation in ICT is being accepted as an indispensable means of meeting the needs of both the teachers and the students. Perhaps, it is in line with this assertion [1] observed that the top trend in the transformation of the teaching and learning process involves the use of e-learning. The commonest method by which e-learning instruction is delivered involves the use of the asynchronous and the synchronous methods of instruction [2, 3]. Asynchronous and synchronous instructions are innovative methods of instructional delivery which teachers can adopt when teaching with ICT facilities.

Asynchronous instruction is an e-learning platform which teachers use to interact with their students beyond the limits of the conventional four corners of the classroom. According to $[4,5]$, asynchronous instruction is defined as a student-centered teaching method that uses elearning resources to facilitate information sharing outside the constraints of time and place among a network of people. Thus, in the asynchronous approach, instruction is usually delivered without the physical presence of the participants (teacher-students presence) at the same time [4]. Thus, for this method, instructions do not take place on real time. Consequently, instructional delivery is not simultaneous as it can take place at any time and from any place. For instance, the teacher may decide to deliver his lesson through Videotape, YouTube, Digital Video Disc (DVD) or Podcast while the students can later respond through the use of communication modes like email.

On the other hand, for synchronous instruction, the participants (teacher-students) are connected instantly via an online communication medium and teaching - learning is taking place simultaneously. Perhaps, it is in this regard that [5] defines the synchronous instruction as a method of instructional delivery on real- time (live) basis using an elearning platform. For the synchronous approach, the teacher controls the sequencing of the lesson delivery which must take place in real time and at the same pace but from different locations. Thus, the participants must be physically present for the lesson that takes place simultaneously from their different locations. In addition, access to all instructional materials and course delivery is done instantly. The use of video conferencing, audio conferencing, internet chats, or Skype media communications 
are the commonest platforms of synchronous instruction. Synchronous learning environments support learning and teaching and offer students and teachers multiple ways of interacting, sharing, and the ability to collaborate and ask questions in real-time through synchronous learning technologies [6]. This close innovative collaboration offers greater opportunity that enhances student-to-teacher and student-to-student interaction.

The asynchronous learning platform has several benefits. Because of its flexibility and self-pace characteristic, the asynchronous learning platform according to [2], improves cognitive participation by way of increasing the ability of the learners to reflect and process course information given by the teacher. An asynchronous learning environment also provides the students with more time to consider all sides of an issue before offering their own educated input [4]. Other major benefits of asynchronous instruction were summarized by [7]. These benefits include: the freedom of students to access course and other instructional materials at any time they choose and from any location with an Internet connection. This allows for accessibility for diverse student populations, ranging from traditional, on-campus students to working professionals, as well as international students in foreign countries.

The current rise in the global use of the synchronous and the asynchronous instructional methods, according to [4], is, as a result of its several benefits, which were found to be effective in improving students' performance in the technologically advanced nations. However, this assertion has not been verified for students of Electrical/Electronic Technology in Colleges of Education in Nigeria.

The Electrical Engineering program in Nigerian Colleges of Education was designed to produce qualified technical teachers and practitioners of technology capable of teaching Basic Technology in the Junior Secondary Schools (JSS). Graduates of this program are expected to start the so much desired revolution of technological development right from the Nigerian schools [8]. In order to ensure effective training of the students, the National Commission for Colleges of Education (NCCE) advocates for the adoption of e-learning innovative teaching and learning methodologies such as synchronous and asynchronous instruction. However, despite the unique features and benefits of these innovative methods of instruction, it has been observed over the years that the current methods of instruction used in training the students of Electrical Engineering at Nigeria Certificate of Education (NCE) level does not seem to be adequate in preparing them to be able to teach and contribute meaningfully to the technological advancement of the nation. Thus, in order to attain the objective of producing competent teachers to teach Electrical Engineering at the nations' secondary schools and also the need to keep up with the rapid technological advancement in the field of Electrical Engineering, it therefore becomes paramount for the lecturers to exploit and adopt innovative e-learning techniques like the synchronous and asynchronous instruction. This is because studies such as those of $[9,10]$ as well as [11] revealed that e-learning platforms involving the use of the synchronous and the asynchronous instructions are capable of not only providing a meaningful learning experience for students, but are also likely to improve their performance and arouse their interest in learning. This has, however, not been verified empirically for students of Electrical Engineering in Nigerian Colleges of Education.
It is against this backdrop that this research sought to investigate the effects of synchronous and asynchronous instructional methods in teaching Electrical Engineering for students of Colleges of Education in Nigeria.

\section{THEORETICAL FRAMEWORK}

The theoretical framework for this study is anchored on the relatively most recent theory of learning known as the connectivism learning theory. For this research, the connectivism theory is supported with the three predominant theories of learning, namely: constructivism, cognitivism and Stimulus - Response (behavourism) theories of learning.

The connectivism learning theory was developed by George Siemens at the University of Manitoba in December, 2004. It is known as the "Learning Theory for the Digital Age" [12]. According to [12], George Siemens' developed the connectivism learning theory as a result of his interest in technology's potential to transform the teaching and learning environment through an e-learning platform. Siemens felt the need to develop the connectivist learning theory as the established theories of the day did not adequately match modern-day, digital learning environments. He described learning as messy, chaotic, social, collaborative, and connected with other activities and interests [13]. Connectivism is therefore defined as the integration of pedagogical principles explored by chaos, network, complexity and self-organization theories. Within the connectivism theory, learning is considered to be a process in which the role of informal information exchange, organized into networks and supported with electronic tools, becomes more and more significant. Learning becomes a continuous, lifelong system of network activities embedded into other activities [14].

Based on his research and experience, Siemens explained that existing learning theories did not provide for the changing nature of learning and learners due to the influence of technological advances. In his groundbreaking paper, Connectivism: A Learning Theory for the Digital Age', [15], he outlined the following principles of connectivism: (1) Learning and knowledge rests in diversity of opinions (2) Learning may reside in non-human appliances (3) The capacity to know more is more critical than what is currently known (4) Nurturing and maintaining connections is needed to facilitate continual learning (5) Currency (accurate, up-to-date knowledge) is the intent of all connectivist learning activities. Connectivism therefore helps to ensure students remain current by facilitating the building of active connections, utilizing intelligent social networking and encouraging student-generated curricula.

Another supporter for revitalizing education through the effective use of technology and connectivism practices is Marc Prensky. Prensky is a speaker, author and consultant in the area of education and learning and has focused on digital game-based learning as one solution to the issue of waning student engagement. According to [16] in his article, Engage Me or Enrage Me, today's learners are no longer interested in or even capable of learning in environments that do not reflect their real-world experiences. Students today come to class equipped with a myriad of wired devices such as cell phones, laptops and iPads. They are constantly in touch, motivated by and responding to their changing world with the spontaneous exchange of knowledge. Instructors that teach with the conventional, 
old-fashion "chalk and talk" approach, [16] asserted, will have difficulty in significantly reaching their target students in this current digital age. Prensky further explained that students' lives are rich in media, communication and creative opportunities outside of school.

\section{A. Implications of Connectivism theory on Synchronous and Asynchronous Instruction:}

On the basis of the discussions so far, the implications of the connectivism theory which is applicable to elearning and of particular interest to this research work on synchronous and asynchronous instruction can be summed up as follows:

- e-learning materials uploaded on the web should be organized into groups or categories to facilitate retention and stimulate students' interest in learning;

- the mode of presentation of the e-learning materials uploaded in the web should be in different styles in order to facilitate transfer to long term memory;

- to promote active participation, teachers should ensure to insert moments of break between presentations on any of the e-learning platform

- students should be given ample opportunity to revisit topics to strengthen retention and enhance their performance;

- teachers should use key words and terms as memory cues on the lecture materials uploaded on the net.

- teachers should not overload short term memory by presenting too much material at once on either the synchronous or asynchronous platform;

These characteristics are required when using innovative teaching platforms like the synchronous and asynchronous instruction in order to make the learning environment authentic, the teaching and learning process student-centered, collaborative, well guided, active and flexible.

Constructivism Theory: A student-centered learning environment is seen as a major enabling element in constructivism. People learn best when they can contextualize what they learn for immediate application and personal meaning. In the process, according to [17], the role of the learner has changed from that of a recipient of knowledge to that of a constructor of knowledge, an autonomous learner with meta-cognitive skills for controlling his/her cognitive processes; the teacher acts as a facilitator who encourages students to discover principles for themselves and to construct knowledge by working to solve realistic problems.

Regardless of the variety, [18] asserted that the constructivist pedagogy puts the learner at the center of the process and sees the teacher as providing support and guidance as well as promoting student's free exploration within a given framework. This point of view is in alignment with the self-pace, individualized characteristics of the synchronous and asynchronous platform of instruction, hence, the relevance of the constructivist theory of learning is stressed in this research.

Cognitivism Theory: Cognitivists believed that responses to environmental stimuli or changes in behavior are indicators of the unobservable inner mental processes that involve the use of memory, motivation and thinking; thus, to them, learning is an internal process and involves thinking.
Most current ideas intended to facilitate student learning draw on our awareness of this mental processing [17]. As a result, cognitive approaches emphasize critical thinking and are increasingly used as a tool in problem-solving in specific disciplines. By drawing an analogy of the human mind with a computer, it often takes a computer information processing model according to which learning is viewed as a process of inputs, managed in a short term memory and processed for long-term recall. On the basis of the discussions so far, the implications of the cognitive theory which is applicable to e-learning and of particular interest to this research work on synchronous and asynchronous instruction can be summed up as follows:

- to promote active participation, teachers should ensure to insert moments of break between presentations on any of the e-learning platform

- Teachers should use key words and terms as memory cues on the lecture materials uploaded on the net.

- students should be given ample opportunity to revisit topics to strengthen retention;

These characteristics of cognitivism are required when using innovative teaching platforms like the synchronous and asynchronous instruction in order to make the learning environment authentic, the teaching and learning process student-centered, collaborative, well guided, active and flexible [5]. Thus, these characteristics were reflected in the preparation of the learning instruction for the students in this research.

Stimulus -Response theory: Although the StimulusResponse approach does not fully utilize the full potential of the emerging e-learning platform, some of its characteristics are still adoptable for digital technology especially in areas of adaptive responses - such as feedback through e-learning assessment tools, presentation of content and use of multiple media to convey information. From the foregoing discussions, it is evident that StimulusResponse theory has an influence in the learning field especially in the implementation and delivery of elearning instruction using the Synchronous and Asynchronous leaning environments and the attainment of Bloom's low level skills. These features were given prominence in the preparation of the instructions for this study.

\section{RESEARCH QUESTIONS}

The following research questions have guided the study:

1. What are the effects of the synchronous and the asynchronous instructional approaches on the students' cognitive achievement in Electrical Engineering?

2. What are the effects of the synchronous and the asynchronous instructional approaches on the students' interest in studying Electrical Engineering?

\section{A. Hypotheses}

The following null hypotheses were formulated and tested at 0.05 level of significance:

$\mathrm{HO}_{1}$ : There is no significant difference in the cognitive achievement scores of students taught Electrical Engineering using the synchronous instruction and those taught with asynchronous instruction 
$\mathrm{HO}_{2}$ : There is no significant difference in the interest mean scores of students' taught Electrical Engineering with the synchronous instruction and those taught with asynchronous instruction

\section{METHODOLOGY}

\section{A. Population of the Study:}

The population of this study is made up of the entire 190 Electrical Engineering students from the Colleges of Education under study. The statistic was obtained from the schools examination officers for 2014/2015. The choice of these students is based on the premise that the NCCE guideline stipulates the selection of a major course at NCE III level. Since the entire population was used for the study, there was no need for sampling.

\section{B. Research Design:}

A quasi-experimental design was adopted for the study. The instruments for data collection include: The Electrical Engineering Cognitive Achievement Test (ETCAT) and The Electrical Engineering Interest Inventory (ETII). The ETCAT was used to measure students' achievement and it is made up of 40 multiple-choice items with four options. Similarly, the researcher assessed the students' interest in Electrical Engineering through the use of ETII. The test comprised 25 items which required students to indicate their preferences in agreement to the ratings. The five point Likert scale was adopted.

\section{Validation and Reliability of Research Instruments:}

The research instruments developed for this study were subjected to both face and content validity by three experts in Industrial and Technology Education from the Federal University of Technology, Minna, Nigeria. The instrument was pilot-tested on 16 respondents in the College of Education, Pankshin, Plateau State. The selection of this school is on the premise that the school and students are not part of the subjects for the research study. The reliability of the instrument was established using the Pearson product moment correlation coefficient and was found to be 0.85 . Similarly, the Kuder-Richardson formula was used to determine the internal consistency of the instrument and the result obtained was 0.78 .

\section{Method of Data analysis}

Mean and standard deviation statistics were used to answer the research questions while the hypotheses formulated for the study was tested using the Analysis of Covariance (ANCOVA) at a 0.05 level of significance.

\section{RESULTS}

The effect of the synchronous and the asynchronous instructional approaches are presented Table 1.

The data presented in Table 1 shows that the asynchronous group had a mean score of 22.63 in the pre-test and a post-test mean of 28.73 . Thus producing pre-test, post-test mean gain of 6.1 , on the other hand, the synchronous group had a mean score of 23.20 in the pre-test and a mean score of 25.48 in the post-test, hence the pre-test, post-test mean gain of the synchronous group was 2.28 . Consequently, this result is an indication that the students in the asynchronous group performed better in the achievement test than the students in the synchronous group.
TABLE I.

PRE-TEST AND POST-TEST MEAN SCORES FOR THE COGNITIVE ACHIEVEMENT TEST

\begin{tabular}{|l|c|c|c|c|}
\hline \multicolumn{1}{|c|}{ Group } & $\mathbf{N}$ & $\frac{\text { pre-test }}{\mathbf{X}}$ & $\begin{array}{c}\text { post-test } \\
\mathbf{X}\end{array}$ & Mean Gain \\
\hline asynchronous & 150 & 22.63 & 28.73 & 6.1 \\
\hline synchronous & 40 & 23.20 & 25.48 & 2.28 \\
\hline
\end{tabular}

TABLE II.

PRE-TEST AND POST-TEST MEAN SCORES FOR THE INTEREST INVENTORY

\begin{tabular}{|l|c|c|c|c|}
\hline \multicolumn{1}{|c|}{ Group } & $\mathbf{N}$ & $\begin{array}{c}\text { pre-test } \\
\overline{\mathbf{X}}\end{array}$ & $\begin{array}{c}\text { post-test } \\
\overline{\mathbf{X}}\end{array}$ & $\begin{array}{c}\text { Mean } \\
\text { Gain }\end{array}$ \\
\hline Asynchronous & 150 & 21.84 & 28.65 & 6.81 \\
\hline Synchronous & 40 & 21.97 & 26.80 & 4.83 \\
\hline
\end{tabular}

TABLE III.

TEST OF SIGNIFICANCE FOR THE COGNITIVE SKILLS ACHIEVEMENT

\begin{tabular}{|l|l|c|c|c|c|c|}
\hline \multicolumn{2}{|c|}{ SOURCE } & $\begin{array}{c}\text { Sum of } \\
\text { Squares }\end{array}$ & df & $\begin{array}{c}\text { Mean } \\
\text { Square }\end{array}$ & F & Sig \\
\hline Between & & 591.950 & 39 & 15.178 & & \\
\hline & $\begin{array}{l}\text { Between } \\
\text { Items }\end{array}$ & 135.200 & 1 & 135.200 & 18.514 & .000 \\
\hline Within & Residual & 35.200 & 39 & 7.303 & & \\
\hline & Total & 420.000 & 40 & 10.500 & & \\
\hline Total & & 1011.950 & 79 & 12.809 & & \\
\hline
\end{tabular}

From Table II the data presented shows that the asynchronous group had a mean score of 21.84 in the pre-test and a post-test mean of 28.65 as a result producing pretest, post-test mean gain of 6.81 , on the other hand, the synchronous group had a mean score of 21.97 in the pretest and a mean score of 26.80 in the post-test making a pre-test, mean gain of the synchronous group to be 4.83 . This result revealed that the students in the asynchronous group developed more interest in studying Electrical Engineering than the students in the synchronous group. As a result, it can be affirmed that the asynchronous instructional approach is more effective in improving students' interest in Electrical Engineering than the synchronous instructional approach.

\section{A. Hypothesis 1}

There is no significant difference in the cognitive achievement mean scores of students taught Electrical Engineering using the synchronous instruction and those taught with the asynchronous instruction

From table III the data presented shows F-calculated values for the mean scores of synchronous and the asynchronous groups in the cognitive skills test on students' achievement in Electrical Engineering. The F-calculated value for the Group is 18.514 with a significance of $F$ at 0.000 which is less than 0.05 . The null-hypothesis is therefore rejected at a 0.05 level of significance because the result shows that there is a significant difference between the effects of the treatments on the students' skills achievement in Electrical Engineering. 


\section{B. Hypothesis 2}

There is no significant difference in the interest mean scores of students' taught Electrical Engineering with the synchronous instruction and those taught with the asynchronous instruction

Results obtained from table IV revealed the Fcalculated values for the mean scores of synchronous and the asynchronous groups in the interest inventory of students' in Electrical Engineering. The F-calculated value for the interest inventory is 1.747 with a significance of $F$ at 0.194 which is greater than at 0.05 . Consequently, the null-hypothesis is therefore accepted at a 0.05 level of significance because the result shows that there is no significant difference in the mean scores of students' interest in Electrical Engineering between students taught with the synchronous approach and those taught with asynchronous approach.

\section{SUMMARY OF FINDINGS}

On the basis of the data collected, and analyzed, as well as of the hypotheses tested, the following are the principal findings of the study:

1. The asynchronous instructional approach is more effective than the synchronous instructional approach with respect to the students' cognitive achievement in Electrical Engineering.

2. The students' interest is stimulated in Electrical Engineering with the use of both the synchronous and the asynchronous instructional approaches; however, the effect of asynchronous one was more, than that of the synchronous.

3. There was a significant difference in the cognitive achievement of students taught Electrical Engineering with the asynchronous instructional approach than those taught with the synchronous instructional approach.

4. There was no significant difference between the mean interest scores of students taught Electrical Engineering with the asynchronous instructional approach and those taught with the synchronous instructional approach

\section{DISCUSSION OF FINDINGS}

The answer to research question one was provided by the data presented in Table 1. The information contained in the table revealed that the asynchronous instructional approach is more effective in improving the students' cognitive achievement than the synchronous instructional approach, because the group taught with the asynchronous instructional approach had higher post- test mean scores than those taught with the synchronous instructional approach. Similarly, the analysis of covariance which was used to test the first hypothesis also revealed that at the calculated $F$ value of 18.514 , with a significance of 0.00 and confidence level of 0.05 , there was a significance difference in the cognitive achievement of students. The interpretation of this result is that the use of the asynchronous instructional approach is more effective than the synchronous instruction in improving students' cognitive achievement in Electrical Engineering. Thus, the implication of this finding is that the asynchronous instructional approach is more effective than the synchronous instructional approach in terms of improving the students' cognitive achievement in Electrical Engineering. This concurs
TABLE IV.

TEST OF SIGNIFICANCE FOR THE INTEREST INVENTORY

\begin{tabular}{|l|l|c|c|c|c|c|}
\hline \multicolumn{2}{|c|}{ SOURCE } & $\begin{array}{c}\text { Sum of } \\
\text { Squares }\end{array}$ & df & $\begin{array}{c}\text { Mean } \\
\text { Square }\end{array}$ & F & Sig \\
\hline Between & & 864.888 & 39 & 22.177 & & \\
\hline & $\begin{array}{l}\text { Between } \\
\text { Items }\end{array}$ & 19.013 & 1 & 19.013 & 1.747 & .194 \\
\hline Within & Residual & 424.487 & 39 & 10.884 & & \\
\hline & Total & 443.500 & 40 & 11.088 & & \\
\hline Total & & 1308.388 & 79 & 16.562 & & \\
\hline
\end{tabular}

with the conclusion of [9], that the achievement of students in cognitive learning was more among the students taught with the asynchronous communication tools than those taught with synchronous communication tools. The finding that asynchronous instruction is more effective that the synchronous instruction might not be unconnected with the fact that the asynchronous instruction is a student-centered teaching method that uses e-learning resources to facilitate information sharing outside the constraints of time and place among a network of people. This assertion is in line with the view of [7], that one of the major elements of the asynchronous instruction is that teaching and learning process can take place at different times and at different places, thus it allows students to schedule their learning activity at their own time, place and pace.

The data presented in Table 2 provided answer to research question two on the effect of the synchronous and the asynchronous instructional approaches on students' interest in studying Electrical Engineering. The result shows that though both the synchronous and the asynchronous instructional approach are effective in improving the students' interest in Electrical Engineering, the effect of asynchronous instruction is higher than that of the synchronous instruction. This finding is consistent with that of [4], who revealed that the use of synchronous and asynchronous e-learning media helps to stimulate attention and maintain students' interest in both theories and concepts under discussion.

However, the use of the asynchronous platform was found to be more effective in stimulating the interest of students according to the findings of the research conducted by [10] as well as [19]. According to these authors, the use of the asynchronous platform is capable of making the class intrinsically interesting and enjoyable, because the platform provides the students' with the opportunity to interact and review the lectures by going online to watch the video over and over again.

A possible explanation for the effectiveness of the asynchronous instructional approach over the synchronous approach in terms of stimulating the students interest is the fact that they (the students) are at liberty to save and download the lecture materials to watch and review the content at their own convenience either online with internet availability or offline (that is, from the downloaded version without connectivity to the net). Thus, according to [19], the use of an asynchronous instructional platform such as the use of YouTube can serve as a motivational and stimulating tool for students, because they can use it as a medium of studying outside the classroom. 


\section{Summary And Future RECOMMENDATIONS}

This study was conducted to determine the effects of the synchronous and the asynchronous instructional approaches concerning the students' achievements and interests in electrical engineering at the Niger State College of Education. The study found out that the asynchronous instructional approach was more effective than the synchronous instruction in enhancing the students' cognitive achievements and interest. The study also found out that there was a significant difference in terms of the performance of students taught with the synchronous instruction when compared with those taught with an asynchronous instruction.

These findings have shown that the use of innovative elearning platforms such as the asynchronous instructional approach is a viable method of instruction which is not only capable of improving the students' performance, but it is also capable of stimulating their interest in learning.

On the basis of the findings of this study, the following recommendations were made:

- The National Commission for Colleges of Education should develop the appropriate frameworks necessary for encouraging the adoption of innovative elearning platforms such as that of the synchronous and the asynchronous instruction

- The management of the Colleges of Education under study should mount a capacity-building program for the training and re-training the lecturers on the use of innovative e-learning teaching methods such as the asynchronous instructional approach

- Lecturers should adopt the asynchronous instructional approach in teaching and learning Electrical Engineering in the Colleges of Education under study.

- The students of Electrical Engineering should also be given adequate orientation on the importance and the use of e-learning in the school system.

\section{REFERENCES}

[1] Skylar, A. A comparison of asynchronous online text-based lectures and synchronous interactive web conferencing lectures. Issues In Teacher Education, Retrieved from http://proxy1.ncu.edu/login.url=http://search.ebscohost.com, 2009. 18(2), pp. 69-84.

[2] Hrastinski, S. Asynchronous \& synchronous E-learning. EDUCAUSE Quarterly, Retrieved from http://net.educause.edu/ir/librar084.pdf. 2008. 31(4), pp. 51-55.

[3] Simonson, M., Smaldino, S., Albright, M., \& Zvacek, S. Teaching and Learning at a Distance: Foundations of Distance Education. (5th ed.). Boston: Pearson. 2012.

[4] Higley, M.. Benefits of synchronous and asynchronous eLearning. Free E-learning Industry.2013. Retrieved from http://elerningindustry.com Siemens, G. Connectivism: A Learning Theory for the Digital Age. 2004. Retrieved November 8, 2014, from http://www.elearnspace.org/Articles/connectivism.htm

[5] Azimzadeh, R. Synchronous verses asynchronous technologies. $2014 . \quad$ https://prezi.com/ygbde6y9ju1p/synchrnous-vsasynchronous -technologies/

[6] E-Learners.com. Synchronous vs. Asynchronous Classes [blog]. 2012. Retrieved from http://www.elearners.com/online-educationesources/online-learning/synchronous-vs-ynchronous-classes/

[7] Mayadas, F. Asynchronous learning networks: A sloan foundation perspective. Journal of Asynchronous Learning Networks, 1997. 1 (1).

[8] National Commission for Colleges of Education, NCCE,. Nigeria Certificate in Education Minimum Standards for Vocational and Technical Education. NCCE Publications, 2012.
[9] Khalil, H. \& Ebner, M. Using electronic communication tools in online group activities to develop collaborative learning skills. In: Proceedings of $1^{\text {st }}$ International Conference on Open Learning: Role, Challenges, and Aspirations, 2013.p. 1-10

[10] Khalid, A. \& Kabilan, M. The use of YouTube in teaching English literature the case of Al-Majma'ah community college, AlMajma'ah university (case study).International Journal of Linguistics 2012. 4, 4 Retrieved November $12^{\text {th }} 2014$ from www.macrothink.org/ijl 525

[11] Lee, C.Y.. A Case Study of using synchronous computermediated communication System for Spoken English teaching and learning based on socio-cultural theory and communicative language teaching approach curriculum. PhD dissertation presented to the Faculty of Education, Ohio University, 2009.

[12] Darrow, S. Connectivism learning theory: Instructional tools for college courses. A thesis submitted in partial fulfillment for Master's Degree in Education. Western Connecticut State University Danbury, CT. 2009.

[13] Siemens, G. Knowing knowledge. 2006 .Retrieved November 8, 2014, from http://ltc.umanitoba.ca/KnowingKnowledge/index.php/Main Page

[14] Bessenyei, I. Learning and teaching in the information society. Elearning 2.0 and Connectivism. 2007. Retrieved November 8, 2014 http://www.ittk.hu/netis/doc/ISCB_eng/12_Bessenyei_final.pdf

[15] Siemens, G. Connectivism: A Learning Theory for the Digital Age. 2004. Retrieved November 8, 2014, from http://www.elearnspace.org/Articles/connectivism.htm

[16] Prensky, M. (2005). Engage Me or Enrage Me: What Today's Learners Demand. Educause Review, 40 (5). Retrieved November 8, 2014 from http://www.educause.edu/ir/library/pdf/erm0553.pdf

[17] Anderson, T. \& Kanuka, H. Using constructivism in technology mediated learning: constructing order out of the chaos in the literature. 1999. Retrieved November $8^{\text {th }}, 2014$ from http://radicalpedagogy.icaap.org/content

[18] Thomas, P.Y. Towards developing a web-based blended learning environment at the University of Botswana. PhD dissertation. University of South Africa. 2010. Available at www.unisa.ac.za

[19] Kelsen, B. Teaching EFL to their Generation: A survey of using youtube as supplementary material with college EFL students in Taiwan. CALL-EJ Online,

\section{AUTHORS}

E. Raymond $(\mathrm{PhD})$ is with Federal University of Technology, PMB 65, Minna, Nigeria. He is presently the Departmental Postgraduate Program Coordinator, Department of Industrial and Technology Education, Federal University of Technology, Minna, Nigeria. (e-mail: emmanuelraymond2@gmail.com)

B. N. Atsumbe is a Professor with the Federal University of Technology, PMB 65, Minna, Nigeria. He is presently a visiting Professor at Modibbo Adamawa University of Technology, Yola and Abubakar Tafawa Balewa University, Bauchi, Nigeria. (e-mail: atsumbe@yahoo.com)

R. O. Okwori is an Associate Professor with the Federal University of Technology, PMB 65, Minna, Nigeria. He is presently the Head of Department Industrial and Technology Education. (e-mail: robertokworifutminna.edu.ng)

M. A. Jebba is a $\mathrm{PhD}$ candidate with Department of Industrial and Technology Education, Federal University of Technology, PMB 65, Minna, Nigeria. He lectures at Niger State College of Education, PMB 39, Minna, Nigeria. (e-mail: adamujebba@gamil.com)

Submitted, 09 March 2015. Published as resubmitted by the authors on 09 April 2015. 